\title{
A Dança Circular Sagrada em um Processo de Humanização do Cuidado Á Saúde
}

\author{
Mendes, Maria Ignês de Araújo; Abath, Guilherme \\ Secretaria de Saúde - Prefeitura da Cidade do Recife — ignesaraujo@hotmail.com
}

INTRODUÇÂO o aumento na expectativa de vida da população se dá, entre outras coisas, pelo desenvolvimento na área de saúde. a sociedade moderna nos dá pouca oportunidade de pensarmos na qualidade de nossas vidas. com o passar dos tempos, o movimento físico do homem, em sua rotina diária, sofreu modificações e as necessidades básicas foram acrescidas de outras, de acordo com o contexto sociocultural. Deixou de ser uma necessidade espontânea e passou a ser mais condicionada pelo desenvolvimento da tecnologia, diminuindo gradativamente a necessidade de movimentação e esforço físico. Outra questão diz respeito às relações humanas que se tornaram pouco valorizadas. Nessa perspectiva, encontramos a Dança Circular Sagrada, como uma atividade de movimento corporal que se constitui como elemento facilitador para a saúde física e emocional dos praticantes e ainda estimula a integração e a convivência prazerosa em grupo. Considerando estas afirmativas, o trabalho em questão é tentar sensibilizar os Gestores Públicos para a adoção da Dança Circular Sagrada, em Unidades de Saúde Pública. OBJETIVOS Sensibilizar Gestores de Unidades da Rede Pública, para a compreensão e adoção da Dança Circular Sagrada como prática sanitária; Promover acolhimento mais humanizado aos usuários do serviço e equipes de saúde; Estimular a formação de multiplicadores na Dança Circular Sagrada. METODOLOGIA a proposta é a de experimentar uma vivência que resulte na adoção da Dança Circular Sagrada como instrumento terapêutico auxiliar, contribuindo na política de humanização em saúde. Este projeto de intervenção comporta um plano de ação a ser desenvolvido seguindo algumas etapas. em um primeiro momento, apresentação do Projeto aos Gestores, objetivando sensibiliza-los. em outro momento, acontecerá a apresentação da Dança Circular Sagrada e sua vivência em quatro oficinas: música, ritmo, gestos e movimentos do corpo, destinados aos profissionais de Unidade de Saúde Pública. RESULTADOS ESPERADOS Esperasse como resultado o apoio dos gestores ao projeto, com a apreensão da Dança Circular Sagrada, como prática válida, eficaz e eficiente, compatível com o que se espera de uma atividade assistencial integrativa e complementar. Estímulo à expansão e implantação da Dança Circular Sagrada em Unidades Públicas. Formação de multiplicadores na Dança Circular Sagrada. Promoção de mais dignidade e respeito na assistência aos usuários e condições de trabalho aos profissionais, pela criação de ambientes mais harmônicos.os. Fortalecimento da relação entre equipe de saúde, usuários e gestores. CONCLUSÃO como síntese final, teremos o fortalecimento do conhecimento teórico em relação ao papel e a força da música e do movimento, salientando a expressão corporal como libertadora de tensões e promotora do equilíbrio físico e emocional, como também o fortalecimento na formação dos profissionais na medida em que a vivência permite a reflexão acerca da universalidade, integralidade, equidade e controle social.

Mendes, Maria Ignês de Araújo; Abath, Guilherme. A Dança Circular Sagrada em um Processo de Humanização do Cuidado Á Saúde. In: Anais do Congresso Internacional de Humanidades \& Humanização em Saúde [= Blucher Medical Proceedings, num.2, vol.1]. São Paulo: Editora Blucher, 2014. ISSN 2357-7282

DOI 10.5151/medpro-cihhs-10856 